\title{
コンクリート強度即時判定方法の実用化に関する研究 \\ STUDIES TOWARD A PRACTICAL USE OF THE METHOD OF IMMEDIATE ESTIMATION OF CONCRETE STRENGTH
}

\author{
池田尚治* \\ By Shoji IKEDA
}

\section{1. 緒霅}

急速硬化によるコンクリート強度即時判定方法は，フ レッシュコンクリートをウェットスクリーニングして得 たモルタルに急結剤を添加し，ただちにこれを高温度で 養生して急速にセメントの水和による強度を発現させ, その強度試験結果からフレッシュコンクリートの材令 28 日強度を推定するものである ${ }^{1) ~ 3)}$. 種々の実験の結 果, この方法を用いることによって材令 1.5 時間程度 のらちにフレッシュコンクリートの材令 28 日強度を相 当の精度で推定することができた.しかし，この方法が コンクリート強度の迅速判定方法として確立し, 実用的 な方法として広く受け入れられるためには多数 の実例による検証, 問題点の摘出とその解決, 工事現場への適用の方法などに関する研究の積 み重ねが必要と思われる。

本文はこのような趣旨に基づき，急速硬化に よるコンクリート強度即時判定方法に関し, 各 種セメントおよび混和材料の影響, 現場試験の ための試験機器の試作, 現場実験による本方法 の適用性の検討，セメントの風化の影響とこれ を改善するための急結剤の改良, 種々の配合の コンクリートの強度推定とその精度の検証, お よび本方法によるコンクリート強度の迅速検査 システムの検討などについて研究を行った結果 を述べるものである.なお，「急速硬化による コンクリート強度即時判定方法」を, 以下に 「急速硬化判定方法」とよぶことにする.

\section{2. 各種セメントおよび混和材料の影響}

セメントには各種のものがあり，また種類が

$*$ 正会只 工博 東京都立大学助教授 工学部土木 工学科
同一でも銘柄によって強度発現の相当に異なるものもあ る. 急速硬化によるモルタルの強度はセメントの水和に よって発現するものであるため，セメントの特性汇影響 を受けることは当然である. そこで入手可能であった市 販のセメントについて急結剂と高温養生との組合せによ る急速硬化特性を調べることとした，ただし，厳密な意 味で各種のセメントの急速硬化特性を調べようとする と, セメントの保管状態や鮮度, セメントのロット, 砂 の表面水と粒度のばらつきなども影響することになり， 実験条件を相当に厳密にすることが必要である. しか し, ここでは実験室で通常取り扱われる状態で試験を行 った.このため, 得られた值は, セメントの種類および 銘柄に対する絶対的な值ではなく，たまたま行った試験

表一1 各種セメントの急速硬化特性

\begin{tabular}{|c|c|c|c|c|c|c|c|c|}
\hline \multirow{2}{*}{$W / C$} & \multirow{2}{*}{$S / C$} & \multirow{2}{*}{$\begin{array}{l}\text { セメント } \\
\text { の銘柄委 } \\
\text { たは種類 }\end{array}$} & \multirow{2}{*}{$\begin{array}{l}7 \\
\text { ㅁ } \\
1\end{array}$} & \multicolumn{4}{|c|}{ 压縮強度 $\sigma_{m 0}\left(\mathrm{~kg} / \mathrm{cm}^{2}\right)$} & \multirow{2}{*}{ 備 } \\
\hline & & & & $1.5 \mathrm{hr}$ & $3.0 \mathrm{hr}$ & $4.5 \mathrm{hr}$ & $5.5 \mathrm{hr}$ & \\
\hline \multirow{5}{*}{0.45} & \multirow{5}{*}{1.81} & $\mathrm{O}$ & 217 & 43 & 61 & 95 & - & \multirow{5}{*}{$\begin{array}{l}\text { (F.M. }=2.64) \\
\text { わずかに風化し } \\
\text { たセメント }\end{array}$} \\
\hline & & $\mathrm{A}$ & 215 & 51 & 71 & 81 & - & \\
\hline & & $\mathrm{s}$ & 219 & 73 & 95 & 100 & - & \\
\hline & & $\mathrm{C}$ & 215 & 78 & 97 & 106 & - & \\
\hline & & M & 207 & 74 & 93 & 103 & - & \\
\hline \multirow{5}{*}{0.60} & \multirow{5}{*}{2.80} & & & & & & & \multirow{5}{*}{$\begin{array}{l}\text { F.M. }=2.64) \\
\text { わずが風化し } \\
\text { たセメント }\end{array}$} \\
\hline & & A & 221 & $\begin{array}{l}24 \\
38\end{array}$ & $\begin{array}{l}60 \\
46\end{array}$ & 71 & - & \\
\hline & & $\mathrm{S}$ & 220 & 50 & 64 & 50 & & \\
\hline & & C & 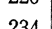 & 43 & 54 & 50 & 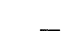 & \\
\hline & & M & 224 & 43 & $\begin{array}{l}54 \\
56\end{array}$ & $\begin{array}{l}50 \\
59\end{array}$ & - & \\
\hline \multirow{6}{*}{0.75} & \multirow{6}{*}{3.85} & & & & & & & \multirow{6}{*}{$\begin{array}{l}\text { (F.M.=2.64) } \\
\text { わずかに風化し } \\
\text { たセメント }\end{array}$} \\
\hline & & $\mathrm{O}$ & 206 & 0 & 9.4 & 40 & 53 & \\
\hline & & A & 223 & 6.2 & 32 & 43 & - & \\
\hline & & $\mathrm{s}$ & 214 & 16 & 38 & 47 & - & \\
\hline & & $\mathrm{C}$ & 213 & 19 & 39 & 44 & - & \\
\hline & & M & 218 & 20 & 47 & 58 & - & \\
\hline \multirow{4}{*}{0.60} & \multirow{4}{*}{2.60} & A & - & 37 & 68 & 81 & - & \multirow{4}{*}{$\begin{array}{c}(\mathrm{F} . \mathrm{M} .=3.13) \\
\left\{\begin{array}{l}(\mathrm{)}) \text { 内は } S / C= \\
2.0 \text { 実験 }\end{array}\right.\end{array}$} \\
\hline & & 早強 $\mathrm{A}$ & - & $\begin{array}{c}32 \\
(32)\end{array}$ & $\begin{array}{l}108 \\
(88)\end{array}$ & $\begin{array}{c}123 \\
(106)\end{array}$ & - & \\
\hline & & 高炉A種 & - & 39 & 70 & 86 & - & \\
\hline & & 高炉B種 & - & 31 & 62 & 86 & - & \\
\hline
\end{tabular}

備考 1. 急結剂は PR1 (改良以前のもの) をセメント重量の $4 \%$ 混入 2. セメントの5ち特に表示のないものは普通ポルトランドセメント 3. 高温養生は $70^{\circ} \mathrm{C} 100 \% \mathrm{RH}$ 


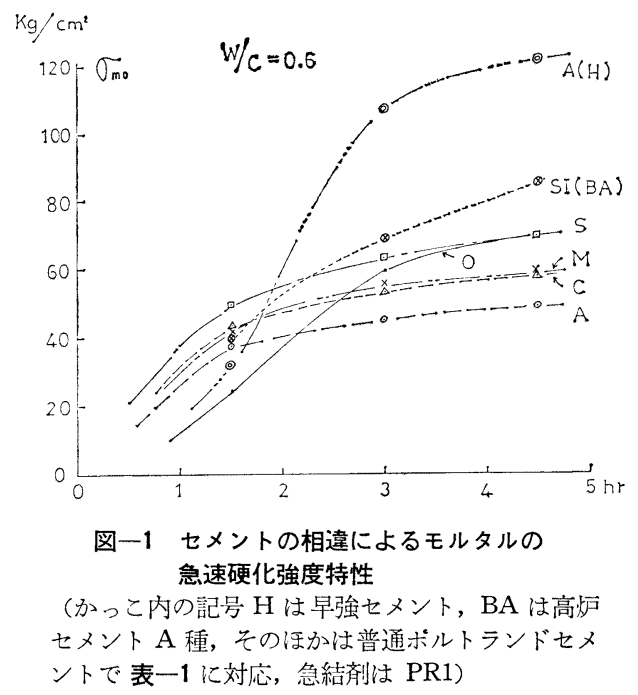

値の例であると考える方がよい。

表一1 に種々のセメントを用いた急速硬化モルタルの 強度試験結果を示す.また 図一1にそのうちの一部を 示す.ここに示されるように，市販されている普通ポル トランドセメントおよび高炉セメントの急速硬化強度特 性は，銘柄の相違によって多少差があるが，ほぼ同様の 特性を持っていることが示された．ただし一部のセメン トで夏期に保管期間が若干経過したものは，急速硬化に よる強度発現が相当に遅れることが示された.これは種 々検討の結果セメントの風化が急速硬化強度特性に大き く影響していることが明らかとなった。これに関しては 後の章で詳しく述べる.

早強セメントについては急速硬化 1.5 時間での強度 は，普通セメントの場合よりわずかに低めであるが，急 速硬化 3.0 時間では普通セメントより若干大きくなる傾 向が見られた。

また高炉セメントの急速硬化強度は普通セメントとほ とんど同じであり， $\mathrm{A}$ 種， $\mathrm{B}$ 種の間の差もわずかであ る. 省資源, 材料の有効な再利用等の観点から, 今後高 炉セメントが多く使用されるようになっても，急速硬化 判定方法を高炉セメントを用いたコンクリートの強度判 定に用いて問題のないことが，この実験結果から判断で きると思われる。

次に混和剂の影響であるが，すでに遅延型の減水剤に 関しては，多量に減水剤が混入された場合は急速硬化モ ルタルも硬化せず，したがって減水剤の過剩投入を検出 できることおよび通常量を混入した場合にはコンクリ 一ト強度の判定にほとんど影響のないことなどの実験結 果を報告したがが，ここではその後代表的な $\mathrm{AE}$ 郕， および $\mathrm{AE}$ 減水剂を用いて行った実験結果を述べる.

図一2に示すように, 通常の使用状態では, $\mathrm{AE}$ 郕お

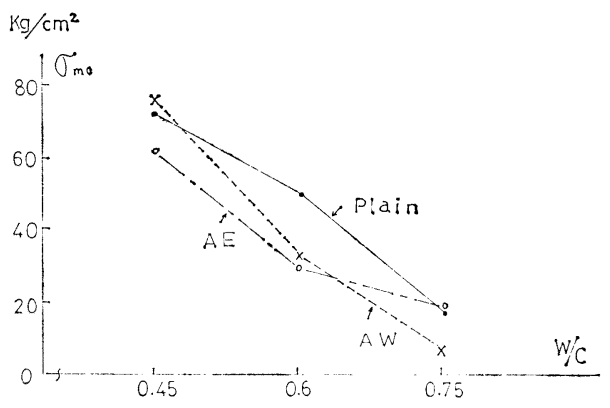

図一2 混和剂がモルタルの急速硬化強度特性 に及ぼす影響

(AW は $\mathrm{AE}$ 減水剂, $\mathrm{AE}$ は $\mathrm{AE}$ 剂, 用いだ メントは S, 忽結剤は PR1, 高温養生 1.5 時閌)

よび $\mathrm{AE}$ 減水剂を混入したモルタルの急速硬化強度は 極端な影響を受けず，強度がプレーンモルタルに比べて 小さくなる場合のあるのは, 架気泡が多く混入された影 響によるものと考えられる。このように，AE コンクリ 一トあるいは隇水剂混入のコンクリートに急速硬化判定 方法を適用するにあたって, 特別な問題点はないものと 思われた。

なお，ここで用いた急結剤はアルミン酸ソーダを主成 分とする市販の急結剤（以下 PR1 とよぶ）である.

\section{3. 現場試験機器の試作}

急速硬化判定方法が実用化し，普及するた奶には，コ ンクリート工事現場あるいはレデーミクストコンクリー 卜工場で簡単に試験できる試験機器の開発が 必要であ る.そこで, 運搬が容易で経済的な試験機器を開発する こととした.

恒温恒湿装置としては, 型枠が同時に 3 個収容できる ように内容積を $300 \times 300 \times 300(\mathrm{~mm})$, とし, 内部が一 様な温度を保つようにファンを取り付けた，加熱方法と しては, タンク内の水を加熱し，この蒸気が室内を循環

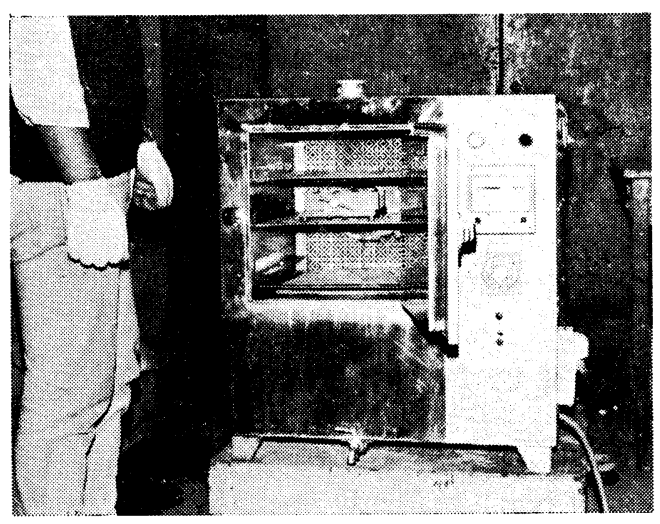

写真一1 試作した恒温恒湿装置とその内部 


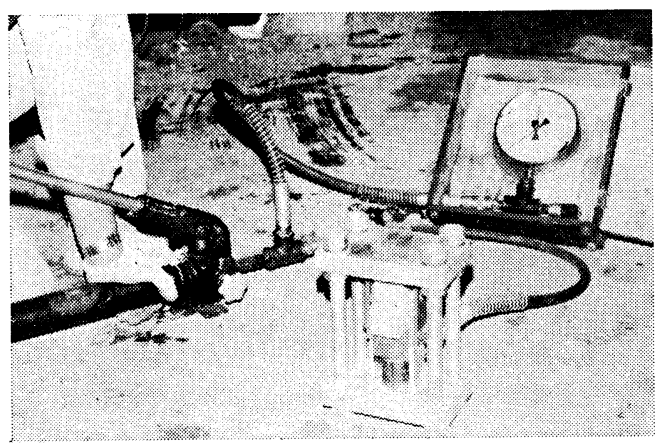

写真一2 試作した圧縮試験機一式

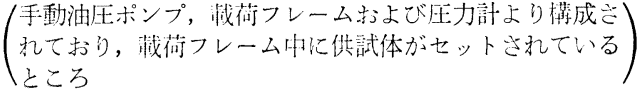

する間接方式とし，電源入力の自動 $\mathrm{ON}, \mathrm{OFF}$ によっ て一定温度が保持できるようにした，湿度については， 発生する水蒸気によって湿度がほぼ $100 \%$ を保つように した. 写真一1 に試作した恒温恒湿装置を示す.

圧縮試験機としては，経済性，簡便性を考え，写真一 2 に示すように手動式油圧ポンプに接続された小型ジャ ッキを載荷フレームに挿入する型式とした．荷重の表示 には，はじめ油圧ポンプにマノメーターを直接取り付け て使用したが，加圧時および破壊時の振動などによりメ 一ターの置き針が動きやすいので, 写真のようにマノメ ーターを独立した箱に収め, ホースで油圧ジャッキと接 繶した。

型枠については一般性のあること, および精度のよい ことなどを考えて，JIS R 5201 に規定されているセメ ント試験用の 3 連型枠の中央に仕切板を入れて用いるこ ととした.

なお,多くの実験の結果, 型枠をさらに小型にすれば養 生時間をいっそう短くできることが考えられること，お よび，中央に仕切板を入れて供試体を作製するのがやや 面倒なことなどの理由により，この方法のための専用の 型枠の試作も行った. 供試体は骨材の最大寸法が $5 \mathrm{~mm}$ のモルタルであるため, 供試体寸法としては断面が 3 $\mathrm{cm} \times 3 \mathrm{~cm}$ 程度でも十分であると思われたので, 荷重の 值が即座に応力度に換算できるように載荷面積がちょう ぞ $10 \mathrm{~cm}^{2}$ となる大きさ, すなわち $\sqrt{10} \mathrm{~cm} \fallingdotseq 3.162 \mathrm{~cm}$ を 2 辺とし, 長さを $5 \mathrm{~cm}$ とする直方体を考えた. 供試

表一2 採取したレデーミクストコンクリートの示方配合

\begin{tabular}{c|c|c|c|c|c|c|c|c|c}
\hline $\begin{array}{c}\text { コンクリー } \\
\text { トの種類 }\end{array}$ & $\begin{array}{c}\sigma_{c k} \\
\left(\mathrm{~kg} / \mathrm{cm}^{2}\right)\end{array}$ & 骨材 & $\begin{array}{c}\text { 粗骨材の } \\
(\mathrm{mm})\end{array}$ & $W / C$ & $W$ & $C$ & $S$ & $G$ & 混 和 成 \\
\hline $\mathrm{N}-1$ & 300 & 普通 & 25 & 0.456 & 145 & 318 & 735 & 1166 & $\mathrm{AE}$ 減水剂 \\
$\mathrm{N}-2$ & 150 & 普通 & 25 & 0.673 & 143 & 212 & 876 & 1117 & " \\
$\mathrm{N}-3^{1)}$ & - & 普通 & 25 & 0.833 & 171 & 205 & 847 & 1079 & " \\
$\mathrm{L}-1$ & 350 & 軽量 & 15 & 0.389 & 168 & 431 & 390 & 490 & " \\
\hline
\end{tabular}

注 1） N-3 は N-2 のコンクリート $14 \mathrm{~kg}$ に水 $200 \mathrm{~g}$ を加えて練り直したもので示方配合は $\mathrm{N}-2$ を基準として算出した。

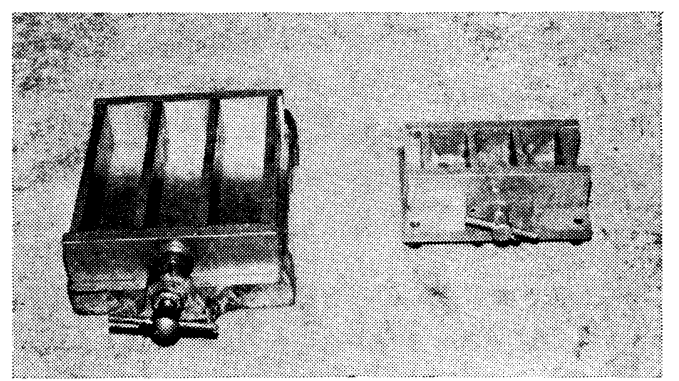

写真一3 供試体作製用型枠

(左は JIS R 5201 の 3 連型染, 右は試作した $10 \mathrm{~cm}^{2} \times 5 \mathrm{~cm}$
寸法の専用 3 連型枠

体を立方体としない理由としては，成形時に隅の部分に 欠点ができやすいからである．写真一3に試作した型枠 を示す.この専用型枠を用いて高温養生 1.5 時間で急速 硬化モルタルを試験した結果, 試験值のばらつきもきわ めてわずかで, $4 \mathrm{~cm} \times 4 \mathrm{~cm}$ 供試体による值とほとんど 同一であった．供試体が小型になれば恒温恒湿装置や圧 縮試験機も小型軽量化することができ，また，採取する コンクリート試料も少なくなるので, 種々の点で有利で ある.

ただし，試作した載荷面積 $10 \mathrm{~cm}^{2}$ の型枠は試作して から日を経ていないため，この論文で掲げた実験值はす べて JIS R 5201 の 3 連型枠を用いて作製した供試体に よる実験結果である.

\section{4. 現場実験}

本方法の実際の工事現場への適用性，および試作した 現場試験機器の使用性の検討を行うため, 高速道路建設 工事現場において現場品質検查実験を実施しだ3.

現場実験は夏期に 4 日間連続して行い, その間, 強度 推定直線作成用の急速硬化モルタルの実験, 8 台のレデ 一ミクストコンクリート車から得た 9 試料による強度推 定実験, および $\phi 10 \mathrm{~cm} \times 20 \mathrm{~cm}$ 型枠による標準養生供 試体の作製などを行った. コンクリートの種類として は，表一2 に入手した配合を示すように，普通骨材コン クリート 3 種類, 軽量骨材コンクリート 1 種類である.

この表で, コンクリート N-3 は N-2 のコンクリート $14 \mathrm{~kg}$ に水 $200 \mathrm{cc}$ を加えて練り直したものである.コ ンクリート L-1 は, 砂, 砂利ともに非 造粒型の人工軽量骨材を用いたものであ る.いずれのコンクリートも普通ポルト ランドセメント $(\mathrm{O})$, および遅延型 $\mathrm{AE}$ 減水剤 (S) が用いられている。 また, この現場実験に使用した急結剤は, PR 1 である。

この現場実験のための強度推定式を定 
めるにあたっては, 次の関係式を定めることが必要であ $\varpi^{1)}$.

まず，コンクリートの材令 28 日圧縮強度とセメント 水比の関係として次式が成り立つ.

$$
\sigma_{28}=k_{1} \frac{C}{W}+k_{2}
$$

同様にして，モルタルのみを練りまぜた場合の急速硬化 モルタルの強度とセメント水比との関係として次式が成 り立つ.

$$
\sigma_{m 0}=m_{01} \frac{C}{W}+m_{02}
$$

次に, ウェットスクリーニングの効果を表わす式として 次式を考える.

$$
\sigma_{m}=a_{1} \sigma_{m 0}+a_{2}
$$

ここで,

$\sigma_{28}$ : 標準供試体によるコンクリートの材令 28 日の圧縮強度

$C / W$ : セメント水比

$\sigma_{m 0}:$ ウェットスクリーニングしないモルタルの 急速硬化圧縮強度

$\sigma_{m}$ : ウェットスクリーニングしたモルタルの急 速硬化圧縮強度

$k_{1}, k_{2}, m_{01}, m_{02}, a_{1}, a_{2}$ : 実験によって定まる定数 式 (1)〜 (3) を用いて, コンクリート強度推定式は次式 のように表わされる。

$$
\sigma_{28}=\left(\frac{k_{1}}{a_{1} \cdot m_{01}}\right) \cdot \sigma_{m}+\left(k_{2}-\frac{a_{1} \cdot m_{02}+a_{2}}{a_{1} \cdot m_{01}} \cdot k_{1}\right)
$$

図一3 湴通コンクリートを対象とし, 当該レデー ミクストコンクリート工場から入手したセメントを用い て行った急速硬化モルタルの $\sigma_{m 0}-C / W$ の関係の実験 結果である。これから最小二乗法により，図に示すよう

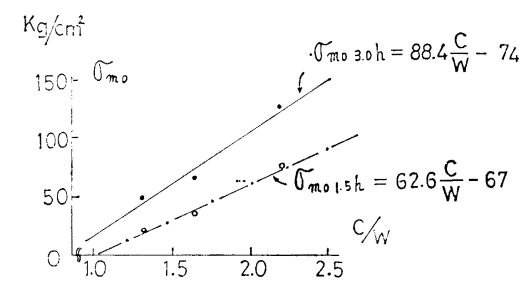

図一3 天然砂による急速硬化モルタル強度 $\sigma_{m 0}$ とセメ ント水比 $\boldsymbol{C} / \boldsymbol{W}$ との関係

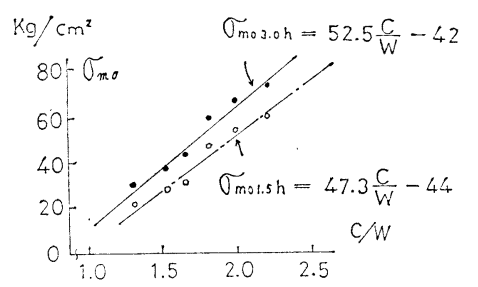

図一4 軽量砂による急速硬化モルタル強度 $\sigma_{m 0}$ と セメント水比 $\boldsymbol{C} / \boldsymbol{W}$ との関係

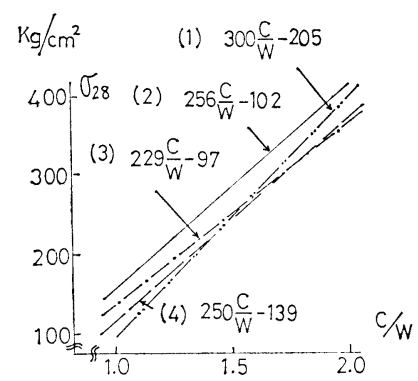

図一5 コンクリートの圧縮強度 $\sigma_{28}$ と $C / W$ との関係 （1）は都立大式 (1)，(2) は都立大式 (2)，(3) 溑都

\begin{tabular}{|c|c|c|c|c|c|c|}
\hline \multirow{2}{*}{$\begin{array}{l}\text { コンクリ } \\
\text { ニトの糧 }\end{array}$} & \multirow{2}{*}{$\begin{array}{l}\text { コンクリ- } \\
\text { トの温度 } \\
\left({ }^{\circ} \mathrm{C}\right)\end{array}$} & \multirow{2}{*}{$\left|\begin{array}{c}\text { スランプ } \\
(\mathrm{cm})\end{array}\right|$} & \multirow{2}{*}{$\begin{array}{l}1.5 \text { 時間 } \\
\text { 撨 定値 } \\
\left(\mathrm{kg} / \mathrm{cm}^{2}\right)\end{array}$} & \multirow{2}{*}{$\begin{array}{l}3.0 \text { 時問 } \\
\text { 推 定值 } \\
\left(\mathrm{kg} / \mathrm{cm}^{2}\right)\end{array}$} & \multicolumn{2}{|c|}{ 実 測 值 ${ }^{1)}$} \\
\hline & & & & & (a) & (b) \\
\hline$N-1(1)$ & 30 & 10.5 & 341 & 331 & 372 & 377 \\
\hline $\mathrm{N}-1(2)$ & - & - & 316 & 361 & 366 & 378 \\
\hline $\mathrm{N}-1(3)$ & 30 & - & 296 & 341 & 357 & - \\
\hline $\mathrm{N}-2$ & 29 & 7.0 & 117 & 131 & 173 & 231 \\
\hline $\mathrm{N}-3$ & - & - & 104 & 112 & 124 & - \\
\hline $\mathrm{L}-1(1)$ & - & 10.0 & 319 & 350 & 324 & - \\
\hline $\mathrm{L}-1(2)$ & 31 & 9.5 & 415 & 406 & 333 & 406 \\
\hline L-1(3) & 33 & 10.0 & 368 & 396 & 285 & - \\
\hline L-1(4) & 32 & 10.0 & 306 & 438 & 307 & 403 \\
\hline
\end{tabular}
公団式, (4) 湕築学会式)

\section{表一3 コンクトートの圧縮強度 $\sigma_{28}$ の推定值と} 実測値の比較

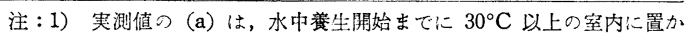
れたものもあり，(b) と供試体の取り扱いが異なる。

な関係式が求まる。図一4 は, 同様にして軽量コンクリ 一トを対象とし，軽量砂を用いて行った実験結果を示 す.ここで，普通コンクリートを対象とした図一3の 実験值は，表一1 または 図一1 に示す実験值のうちの 標準的な值とある程度異なった結果となっている．これ は夏期のため使われたセメントが必ずしも新鮮な状態で なかったことによるものと思われる．

強度推定式を定めるに必要な定数としては, 式 (3)の $a_{1}, a_{2}$ および式(1) の $k_{1}, k_{2}$ が必要であるが，ここでは $a_{1}, a_{2}$ としてこれ以前に行った実験結果 ${ }^{1)}$ から，それぞ れ 1.02 および 32 を用いることとした。 また， $k_{1}, k_{2}$ に ついては 図一5 に示す都立大式 (2) を用いることとし た.

これらの定数を用いて定めた強度推定式は次のように なる・

普通コンクリートの場合 :

$$
\sigma_{28}=5.31 \sigma_{m 1.5 h}-34 \mathrm{~kg} / \mathrm{cm}^{2}
$$

（高温養生 1.5 時間の場合）

$$
\sigma_{28}=4.78 \sigma_{m 3.0 h}-50 \mathrm{~kg} / \mathrm{cm}^{2}
$$

(高温養生 3.0 時間の場合)

軽量コンクリートの場合 :

$$
\sigma_{28}=4.01 \sigma_{m 1.5 h}+44 \mathrm{~kg} / \mathrm{cm}^{2}
$$

（高温養生 1.5 時間の場合） 
$\sigma_{28}=2.84 \sigma_{m 3.0 h}+21 \mathrm{~kg} / \mathrm{cm}^{2}$

（高温養生 3.0 時間の場合）

表一3に，これらの推定式を用いて推定したコンクリ 一ト強度, および実測した材令 28 日のコンクリート強 度の比較を示す.

表一3 の中で, 実測值は, 標準養生の円柱供試体によ る材令 28 日の圧縮強度であり, (a) は成形後に現場事 務所に一時置いてから大学の養生槽に運搬したもの，

（b）は現場で成形し，レデーミクストコンクリートプラ ントで養生し，試験されたものである.（a）と（b）と では值が相当に異なるものもあるが，これは供試体の取 扱いが若干異なったこと, 特に（a）の軽量コンクリー トの場合は, 試料採取から水中養生するまで $30^{\circ} \mathrm{C}$ 以上 の気温中に置いたため, 材令 28 日の強度が相当低めに 出たものと思われた ${ }^{4)}$.

このように，この現場実験では実測強度の值自体が， 供試体の取り扱いなどの影響で值がばらついており，こ れと即時判定による推定值を直接比較するのはやや問題 であるが，概略の傾向を知る意味で，推定值と実測值と をまとめて 図一6に対比した。

これから明らかなように，設計基準強度 $\sigma_{c k}$ が 150 $\mathrm{kg} / \mathrm{cm}^{2}$ と $300 \mathrm{~kg} / \mathrm{cm}^{2}$ ないし $350 \mathrm{~kg} / \mathrm{cm}^{2}$ のコンクリー トに対し, 推定值は十分その品質を区別しており, 本研 究の方法を現場に適用することにより，材令 1.5 時間

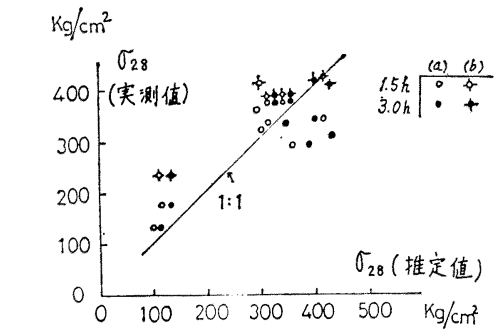

\section{図一6 コンクリートの圧縮強度 $\sigma_{28}$ の実測值と推 定值との比較}

程度でフレッシュコンクリートの品質判定を容易に行う ことが可能であることが示された．なお，図一4 に示さ れたように, 軽量モルタルの急速硬化による強度発現特 性は 図一3 の普通モルタルの場合と若干異なっている が，これは試料を重量で計量したため相対的に急結剤の 量が少なくなったこと，軽量細骨材中の空隊が高温養生 の際に供試体内部の温度上昇に影響を及ぼしたことなど の原因によるものと思われる.

試作した現場試験機器の使用, および軽量コンクリー トの強度判定など, この現場実験において初めて経験し たことが多くあったにもかかわらず，本方法によるコン クリート強度の即時判定はほぼ満足な成果が得られたの であり，本方法が容易に工事現場におけるコンクリート
の品質検查に適用できることが確かめられたのである. 今回の現場実験で用いた急結剤は改良前の PR1 であ り，また試験機器も改良の余地があったので，これらの 改良により推定值の精度をさらに向上させることが可能 であると思われた.

\section{5. 急結剤の改良}

前章までに 述べたように, 急速硬化モルタルの強度 は, セメントの種類あるいは銘柄による差よりも，セメ ントの風化の状態による影響にきわめて敏感であるよう に思われた．セメントの風化の影響は，通常の養生によ るコンクリートの強度を低下させること卢，風化は高温 高湿の状態の時に大きく進行すること到などが報告され ているが，急速硬化モルタルの強度に及ぼす影響は通常 の養生の場合に比べ相当に大きい.このため, 若干風化 したセメントを用いたコンクリートの強度を急速硬化判 定方法によって推定する場合，急速硬化モルタルの強度 発現が風化の程度に応じて変動し, 強度判定の精度を大 幅に低下させることにもなる，そこで，セメントの風化 の影響が過大に現われないようにするための急結剤の改 良が必要となってきた．セメントの風化は，セメントが 空気中の炭酸ガスと反応してセメント粒子表面が炭酸化 されることによるため,一つの試みとして強アルカリの 薬剤を混入することにより，炭酸化の影響をある程度除 くことが可能ではないかと考えた. 強アルカリ剤とし て，容易に入手でき効果のあるものとして苛性ソーダお よび苛性カリが考えられるので，これを用いて予備的な 実験を行った。

図一7に風化の程度と強アルカリ剂の効果の関係につ いて予備実験を行った結果を示す．この図に示すよう に，市販の急結剤（PR1）のみではセメントの風化の影 響を大きく受け，急速硬化モルタルの強度が大きく低下 するのに対して，苛性カリを加えた場合には，風化の影 響を相当に低減させる結果を得た。この方法を詳細に検 討するために, 水セメント比を 2 種類, 強アルカリ剤の

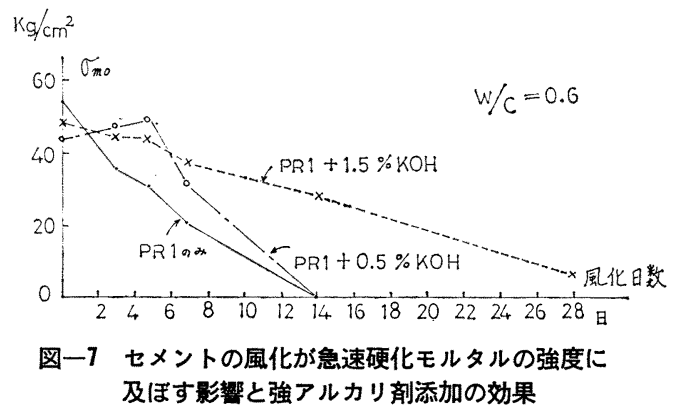

(A セメント使用，高温養生 1.5 時間，風化は $20^{\circ} \mathrm{C}, 70 \%$ RH 以下とした) 


\section{表ー4 急結剈の改良効果を調べた実験結果}

\begin{tabular}{|c|c|c|c|c|c|c|c|c|c|c|}
\hline \multirow{2}{*}{\multicolumn{2}{|c|}{$\begin{array}{c}\text { 強アルカリ郕 } \\
C \times \%\end{array}$}} & \multirow{3}{*}{$\begin{array}{l}\text { 風 } \\
\text { 华 } \\
\text { 数 }\end{array}$} & \multicolumn{8}{|c|}{ モルタルの正縮強度 $\left(\mathrm{kg} / \mathrm{cm}^{2}\right), （ ）$ 内はパーセント } \\
\hline & & & \multicolumn{4}{|c|}{$W / C=0.40$} & \multicolumn{4}{|c|}{$W / C=0.70$} \\
\hline 名 称 & $\%$ & & $1.5 \mathrm{hr}$ & $3.0 \mathrm{hr}$ & $4.5 \mathrm{hr}$ & $\mid \begin{array}{c}\text { 標隻養生 } \\
\sigma_{m 28}\end{array}$ & $1.5 \mathrm{hr}$ & $3.0 \mathrm{hr}$ & $4.5 \mathrm{hr}$ & 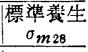 \\
\hline \multirow{3}{*}{-} & \multirow{3}{*}{0} & 0 & $\begin{array}{c}118 \\
(100)\end{array}$ & $\begin{array}{c}152 \\
(100)\end{array}$ & $\begin{array}{l}162 \\
(100)\end{array}$ & $\begin{array}{c}820 \\
(100)\end{array}$ & $\begin{array}{c}6.4 \\
(100)\end{array}$ & $\begin{array}{l}36.2 \\
(100)\end{array}$ & $\begin{array}{l}43.2 \\
(100)\end{array}$ & $\begin{array}{c}398 \\
(100)\end{array}$ \\
\hline & & 1 & $\begin{array}{c}80 \\
(68)\end{array}$ & $\begin{array}{l}141 \\
(93)\end{array}$ & $\begin{array}{l}155 \\
(96)\end{array}$ & $\begin{array}{l}772 \\
(94)\end{array}$ & $\begin{array}{c}0 \\
(0)\end{array}$ & $\begin{array}{r}15.0 \\
(41)\end{array}$ & $\begin{array}{c}38.7 \\
(90)\end{array}$ & $\begin{array}{l}366 \\
(92)\end{array}$ \\
\hline & & 2 & $\begin{array}{c}31.6 \\
(27)\end{array}$ & $\begin{array}{l}111 \\
(73)\end{array}$ & $\begin{array}{l}128 \\
(79)\end{array}$ & $\begin{array}{l}727 \\
\text { (89) }\end{array}$ & $\begin{array}{c}0 \\
(0)\end{array}$ & $\begin{array}{c}0 \\
(0)\end{array}$ & $\begin{array}{c}21.8 \\
(50)\end{array}$ & $\begin{array}{l}312 \\
(78)\end{array}$ \\
\hline \multirow{6}{*}{$\mathrm{KOH}$} & \multirow{3}{*}{0.5} & 0 & $\begin{array}{c}110 \\
(100)\end{array}$ & $\begin{array}{c}142 \\
(100)\end{array}$ & $\begin{array}{c}159 \\
(100)\end{array}$ & - & $\begin{array}{l}23.6 \\
(100)\end{array}$ & $\begin{array}{l}39.6 \\
(100)\end{array}$ & $\begin{array}{l}45.2 \\
(100)\end{array}$ & - \\
\hline & & 1 & $\begin{array}{l}111 \\
(101)\end{array}$ & $\begin{array}{l}152 \\
(107)\end{array}$ & $\begin{array}{l}154 \\
(97)\end{array}$ & - & $\begin{array}{l}9.1 \\
(39)\end{array}$ & $\begin{array}{c}27.2 \\
(69)\end{array}$ & $\begin{array}{c}35.2 \\
(78)\end{array}$ & - \\
\hline & & 2 & $\begin{array}{c}74 \\
(67)\end{array}$ & $\begin{array}{l}122 \\
(86)\end{array}$ & $\begin{array}{l}124 \\
(78)\end{array}$ & - & $\begin{array}{c}0 \\
(0)\end{array}$ & $\begin{array}{c}20.6 \\
(52)\end{array}$ & $\begin{array}{r}31.9 \\
(71)\end{array}$ & - \\
\hline & \multirow{3}{*}{1.0} & 0 & $\begin{array}{c}102 \\
(100)\end{array}$ & $\begin{array}{c}128 \\
(100)\end{array}$ & $\begin{array}{l}135 \\
(100)\end{array}$ & - & $\begin{array}{l}33.3 \\
(100)\end{array}$ & $\begin{array}{l}44.8 \\
(100)\end{array}$ & $\begin{array}{l}47.4 \\
(100)\end{array}$ & - \\
\hline & & 1 & $\begin{array}{c}126 \\
(124)\end{array}$ & $\begin{array}{c}164 \\
(128)\end{array}$ & $\begin{array}{c}166 \\
(123)\end{array}$ & - & $\begin{array}{c}28.0 \\
(84)\end{array}$ & $\begin{array}{c}36.1 \\
(81)\end{array}$ & $\begin{array}{c}42.0 \\
(89)\end{array}$ & - \\
\hline & & 2 & $\begin{array}{c}106 \\
(104)\end{array}$ & $\begin{array}{l}134 \\
(105)\end{array}$ & $\begin{array}{l}148 \\
(110)\end{array}$ & - & $\begin{array}{c}19.2 \\
(58)\end{array}$ & $\begin{array}{r}33.0 \\
(74)\end{array}$ & $\begin{array}{c}34.8 \\
(73)\end{array}$ & - \\
\hline \multirow{6}{*}{$\mathrm{NaOH}$} & \multirow{3}{*}{0.5} & 0 & $\begin{array}{c}103 \\
(100)\end{array}$ & $\begin{array}{c}125 \\
(100)\end{array}$ & $\begin{array}{l}134 \\
(100)\end{array}$ & - & $\begin{array}{l}31.1 \\
(100)\end{array}$ & $\begin{array}{l}42.3 \\
(100)\end{array}$ & $\begin{array}{l}47.0 \\
(100)\end{array}$ & - \\
\hline & & 1 & $\begin{array}{c}109 \\
(106)\end{array}$ & $\begin{array}{c}132 \\
(106)\end{array}$ & $\begin{array}{l}150 \\
(112)\end{array}$ & - & $\begin{array}{c}19.7 \\
(63)\end{array}$ & $\begin{array}{c}28.9 \\
(68)\end{array}$ & $\begin{array}{c}33.8 \\
(72)\end{array}$ & - \\
\hline & & 2 & $\begin{array}{c}87 \\
(85)\end{array}$ & $\begin{array}{l}106 \\
(85)\end{array}$ & $\begin{array}{l}124 \\
(93)\end{array}$ & - & $\begin{array}{r}12.2 \\
(39)\end{array}$ & $\begin{array}{r}25.6 \\
(61)\end{array}$ & $\begin{array}{c}30.6 \\
(65)\end{array}$ & - \\
\hline & \multirow{3}{*}{1.0} & 0 & $\begin{array}{c}100 \\
(100)\end{array}$ & $\begin{array}{c}118 \\
(100)\end{array}$ & $\begin{array}{l}133 \\
(100)\end{array}$ & - & $\begin{array}{l}39.7 \\
(100)\end{array}$ & $\begin{array}{l}48.9 \\
(100)\end{array}$ & $\begin{array}{l}55.4 \\
(100)\end{array}$ & - \\
\hline & & 1 & $\begin{array}{l}107 \\
(107)\end{array}$ & $\begin{array}{l}126 \\
(107)\end{array}$ & $\begin{array}{c}143 \\
(108)\end{array}$ & - & $\begin{array}{c}36.6 \\
(92)\end{array}$ & $\begin{array}{l}51.2 \\
(105)\end{array}$ & $\begin{array}{l}56.5 \\
(102)\end{array}$ & - \\
\hline & & 2 & $\begin{array}{l}89 \\
(89)\end{array}$ & $\begin{array}{c}120 \\
(102)\end{array}$ & $\begin{array}{l}131 \\
(98)\end{array}$ & - & $\begin{array}{c}32.8 \\
(83)\end{array}$ & $\begin{array}{c}41.9 \\
(86)\end{array}$ & $\begin{array}{c}48.1 \\
(87)\end{array}$ & - \\
\hline
\end{tabular}

俑考 1. 急結剂は PR1 をモルタル重量の $1 \%$ 使用

2. 風化は $20^{\circ} \mathrm{C}, 80 \% \mathrm{RH}$ の恒温室でビニール上に $2 \sim 3 \mathrm{~cm}$ 厚で放置

3. セメントは普通ポルトランドセメント $(0)$

使用をセメント量の $0,0.5 \%, 1 \%$ と変化させて実験 を行った. その結果を 表一4 および 図一8 亿示す.こ の実験では合わせて標準養生の供試体に対する風化の影 響も求めたが, 2 日間 $20^{\circ} \mathrm{C}, 80 \% \mathrm{RH}$ でセメントを風化 させた場合,風化させないセメントを用いた場合に比べ， 材令 28 日に拉ける強度は $W / C=0.4$ で $89 \%, W / C$ $=0.7$ で 78\% であって, 強アルカリ剤を用いない急速 硬化モルタルの場合に比べると強度低下はきわめて少な

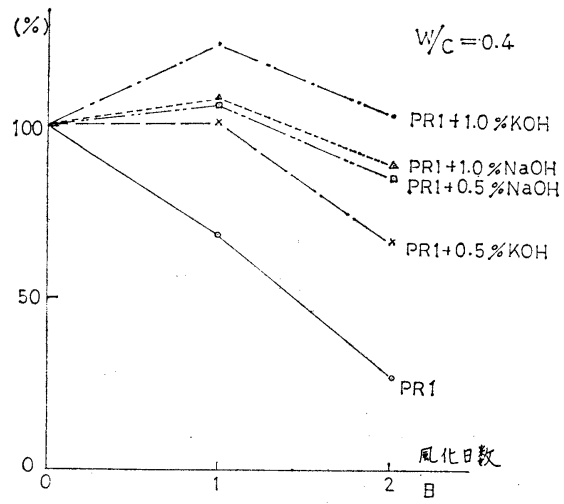

（a）水セメント比 0.4 の場合
いことがわかる.

急速硬化モルタルの場 合には, PR1 に加えて苛性ソーダをセメント量の $1 \%$ 加えると $W / C$ が $70 \%$ の場合でもほ ぼ風化の影響が除去される結果が得られ たのである.強アルカリ鼡の種類および その最適添加量としてはさらに多くの実 験が必要であるが, 現在までの実験結果 からは，苛性ソーダをセメント量の $1 \%$ 程度急結剤に加えて使用すれば, セメン トの風化による影響を除去するのに適当 であると思われた．苛性ソーダなどの強 アルカリ剂は劇薬であり，取り扱いに注 意が必要であるので, セメントの風化を 考慮する必要のないときは市販の急結剤 のみの使用でもよいものと思われる．

また，セメントの風化状態を迅速に調 べたい場合, あるいは風化しかけたセメ ントの使用を防止したい場合には，急結 剤のみを用いる方が急速硬化モルタルに 敏感に影響するために好ましい場合も考 えられる。

急結剤に苛性ソーダなどの強アルカリ 剤を加えると, 水セメント比が大きい場 合, 急結剤のみの混入に比べて初期強度 が増大し，短時間で安定した強度になることが認められ た.したがって, 急結剤に苛性ソーダを一定量加えた薬 剤を急速硬化判定方法の専用の薬剤として使用すれば, 急速硬化判定方法の精度の向上と高温養生時間の短縮を 計ることが可能であると思われた。

\section{6. コンクリート強度判定による検証}

急速硬化判定方法の精度, 信頼度などを確認する意味 で, セメントの銘柄, 配合, 混和剤の有無, コンクリー

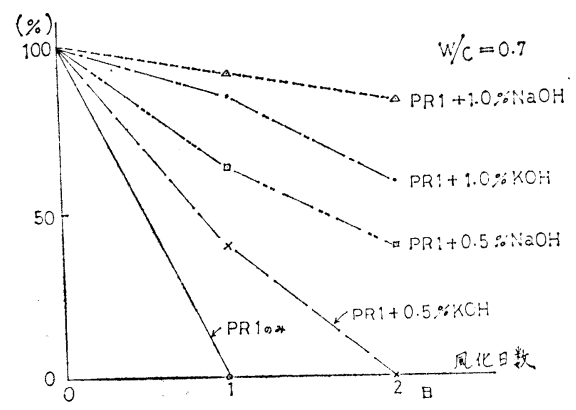

(b) 水セメント比 0.7 の場合

図一8 セメントの風化に対する急結剤の改良効果を調へた実験結果（高温養生 1.5 時閒における圧縮強度の百分率） 
表一5 コンクリート強度判定の実験結果

\begin{tabular}{|c|c|c|c|c|c|c|c|c|c|c|c|c|c|c|c|c|}
\hline \multirow{3}{*}{ No. } & \multirow{3}{*}{$\begin{array}{r}\text { 種セ } \\
y \\
y \\
⺊ \\
\text { 類の }\end{array}$} & \multicolumn{2}{|c|}{ 韲 和 斉 } & \multicolumn{3}{|c|}{ 配 } & \multirow{3}{*}{$\begin{array}{l}\text { ス } \\
\overline{7} \\
y \\
7 \\
(\mathrm{~cm})\end{array}$} & \multirow{3}{*}{$\begin{array}{c}\text { 空 } \\
\text { 気 } \\
\text { 量 } \\
(\%)\end{array}$} & \multirow{3}{*}{$\begin{array}{c}\text { 卜換 } \\
\text { 水算 } \\
\text { 比艺 } \\
⿱ 亠 乂 \\
ン\end{array}$} & \multirow{3}{*}{$\begin{array}{c}\text { 縮トコ } \\
\text { 強のン } \\
\text { 度標ク } \\
\text { 渑リ } \\
\text { 压। } \\
\left(\mathrm{kg} / \mathrm{cm}^{2}\right)\end{array}$} & \multicolumn{3}{|c|}{$\begin{array}{c}\text { ウェットスクリーント } \\
\text { モルタルの縮強度 } \\
\left(\mathrm{kg} / \mathrm{cm}^{2}\right)\end{array}$} & \multicolumn{3}{|c|}{$\begin{array}{c}\text { モルタルの医縮強度 } \\
\left(\mathrm{kg} / \mathrm{cm}^{2}\right)\end{array}$} \\
\hline & & \multirow{2}{*}{ 種 類 } & \multirow{2}{*}{$\begin{array}{c}C \times \% \\
(\%)\end{array}$} & \multirow{2}{*}{$W / C$} & \multirow{2}{*}{$s / a$} & \multirow{2}{*}{$\left|\begin{array}{c}C \\
\left(\mathrm{~kg} / \mathrm{m}^{3}\right)\end{array}\right|$} & & & & & \multicolumn{2}{|c|}{ 急速硬化 } & \multirow{2}{*}{$\frac{\text { 標 準 }}{28 \text { 日 }}$} & \multicolumn{2}{|c|}{ 急速硬化 } & \multirow{2}{*}{$\frac{\text { 標 準 }}{28 \text { 日 }}$} \\
\hline & & & & & & & & & & & $1.5 \mathrm{hr}$ & $3.0 \mathrm{hr}$ & & $1.5 \mathrm{hr}$ & $3.0 \mathrm{hr}$ & \\
\hline 1 & \multirow{10}{*}{ 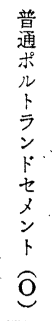 } & AW & 0.25 & 0.70 & 0.42 & 214 & 9.0 & 4.3 & 1.27 & 216 & 35.6 & 51.7 & 388 & 33.5 & 47.7 & 366 \\
\hline 2 & & $"$ & $"$ & 0.564 & 0.38 & 254 & 9.5 & 3.9 & 1.62 & 351 & 54.0 & 72.5 & 504 & 52.9 & 81.9 & 530 \\
\hline 3 & & " & " & 0.40 & 0.34 & 380 & 8.5 & 4.3 & 2.24 & 498 & 100 & 126 & 711 & 92.1 & 134 & 708 \\
\hline 4 & & $\mathrm{AE}$ & 0.025 & 0.70 & 0.42 & 229 & 9.5 & 4.3 & 1.29 & 254 & 46.0 & 57.1 & 430 & 28.3 & 37.5 & 336 \\
\hline 5 & & $"$ & $"$ & 0.55 & 0.38 & 282 & 9.0 & 4.1 & 1.65 & 331 & 62.9 & 80.0 & 539 & 50.2 & 66.9 & 481 \\
\hline 6 & & $"$ & 0.045 & 0.40 & 0.34 & 420 & 9.5 & 4.3 & 2.26 & 412 & 97.0 & 123 & 704 & 99.0 & 120 & 640 \\
\hline 7 & & $A W$ & 0.25 & 0.60 & 0.40 & 272 & 18.5 & 5.0 & 1.45 & 293 & 46.7 & 62.7 & 446 & 40.8 & 62.3 & 456 \\
\hline 8 & & $"$ & " & 0.50 & 0.38 & 332 & 18.0 & 4.8 & 1.76 & 369 & 56.5 & 85.8 & 584 & 51.3 & 87.3 & 574 \\
\hline 9 & & $\mathrm{AE}$ & 0.025 & 0.60 & 0.40 & 287 & 17.5 & 4.2 & 1.52 & 317 & 52.1 & 71.3 & 533 & 44.6 & 54.6 & 462 \\
\hline 10 & & $"$ & " & 0.50 & 0.38 & 354 & 18.5 & 3.9 & 1.85 & 374 & 68.3 & 81.9 & 561 & 67.5 & 84.6 & 597 \\
\hline 11 & \multirow{10}{*}{ 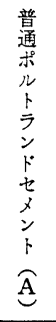 } & $\mathrm{AW}$ & 0.25 & 0.70 & 0.42 & 217 & 8.0 & 5.0 & 1.23 & 228 & 37.5 & 50.9 & 332 & 32.7 & 46.0 & 310 \\
\hline 12 & & $"$ & " & 0.55 & 0.38 & 264 & 8.5 & 5.1 & 1.54 & 343 & 68.5 & 86.4 & 503 & 60.6 & 85.0 & 453 \\
\hline 13 & & $"$ & $"$ & 0.40 & 0.34 & 385 & 8.5 & 3.8 & 2.31 & 472 & 119 & 148 & 747 & 121 & 151 & 619 \\
\hline 14 & & AE & 0.025 & 0.70 & 0.42 & 227 & 7.0 & 4.7 & 1.25 & 209 & 41.5 & 53.1 & 333 & 39.6 & 49.6 & 319 \\
\hline 15 & & $"$ & " & 0.55 & 0.38 & 287 & 7.5 & 4.0 & 1.66 & 333 & 73.9 & 90.6 & 522 & 62.1 & 71.4 & 464 \\
\hline 16 & & $"$ & 0.045 & 0.40 & 0.34 & 425 & 9.5 & 4.0 & 2.30 & 418 & 109 & 129 & 708 & 105 & 118 & 548 \\
\hline 17 & & AW & 0.25 & 0.60 & 0.40 & 272 & 18.5 & 5.3 & 1.42 & 305 & 55.2 & 75.4 & 460 & 54.8 & 78.5 & 404 \\
\hline 18 & & " & " & 0.50 & 0.38 & 336 & 19.0 & 5.4 & 1.71 & 374 & 71.0 & 92.1 & 533 & 80.6 & 111 & 519 \\
\hline 19 & & AE & 0.025 & 0.60 & 0.40 & 290 & 18.0 & 5.3 & 1.44 & 263 & 51.9 & 64.8 & 476 & 55.2 & 65.6 & 442 \\
\hline 20 & & $"$ & $"$ & 0.50 & 0.38 & 354 & 17.5 & 4.8 & 1.77 & 327 & 64.6 & 81.1 & 561 & 71.4 & 85.8 & 526 \\
\hline 21 & \multirow{10}{*}{ 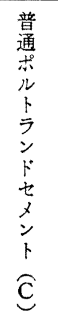 } & AW & 0.25 & 0.70 & 0.42 & 214 & 8.0 & 5.0 & 1.22 & 212 & 29.8 & 38.4 & 287 & 33.1 & 39.2 & 306 \\
\hline 22 & & " & $"$ & 0.55 & 0.38 & 256 & 9.0 & 4.4 & 1.60 & 325 & 51.9 & 65.8 & 506 & 55.8 & 65.4 & 432 \\
\hline 23 & & $"$ & $"$ & 0.40 & 0.34 & 375 & 9.0 & 3.8 & 2.25 & 457 & 107 & 123 & 666 & 102 & 117 & 623 \\
\hline 24 & & $\mathrm{AE}$ & 0.025 & 0.70 & 0.42 & 224 & 9.5 & 5.6 & 1.19 & 195 & 29.6 & 38.8 & 319 & 25.8 & 32.7 & 306 \\
\hline 25 & & " & " & 0.55 & 0.38 & 280 & 10.5 & 5.2 & 1.55 & 317 & 44.6 & 53.3 & 472 & 41.8 & 52.7 & 436 \\
\hline 26 & & " & 0.045 & 0.40 & 0.34 & 410 & 10.5 & 5.1 & 2.16 & 422 & 92.9 & 105 & 666 & 79.6 & 96.4 & 525 \\
\hline 27 & & $\mathrm{AW}$ & 0.25 & 0.60 & 0.40 & 265 & 18.5 & 4.5 & 1.48 & 297 & 49.8 & 64.2 & 484 & 43.8 & 57.9 & 398 \\
\hline 28 & & " & $"$ & 0.50 & 0.38 & 336 & 19.0 & 4.4 & 1.80 & 356 & 59.4 & 71.3 & 527 & 63.1 & 83.3 & 521 \\
\hline 29 & & $\mathrm{AE}$ & 0.025 & 0.60 & 0.40 & 283 & 19.5 & 5.8 & 1.39 & 286 & 46.4 & 58.3 & 472 & 35.6 & 43.3 & 423 \\
\hline 30 & & " & $"$ & 0.50 & 0.38 & 348 & 19.5 & 5.3 & 1.72 & 355 & 52.9 & 64.2 & 522 & 53.1 & 65.0 & 526 \\
\hline
\end{tabular}

備考 1. 粗骨材の最大寸法 $=25 \mathrm{~mm}$, 細骨材の粗粒率 $=2.86$, 川砂, 川砂利使用

2. 急結郕は改良急結郕 (PR2) をモル夕ル重量の $1 \%$ 使用

3. 混和剂 $\mathrm{AW}$ は $\mathrm{AE}$ 減水剂, $\mathrm{AE}$ は $\mathrm{AE}$ 郕

4. 高温蕵生は $70^{\circ} \mathrm{C}, 100 \% \mathrm{RH}$

トの練りまぜ状態などを 変化させて 検証することとし た.

急結剂としては市販の急結剤 (PR1) の 20\%を苛性 ソーダで置き換えたもの（以後 PR2 とよぶ）用いた.

表一5 に実験の結果を示す.このうちの急速硬化モル タルの強度発現特性の一部を図一9に示す. これらの表 および図から次の事柄が認められる. すなわち, 急結剤 を改良して用いたため初期強度の増大が大きく, 早い時 間に急速硬化モルタルの強度が安定している．また，七 メントの銘柄および混和剤の相違による強度特性の相違 も一部を除き大きくない. モルタルのみを練りまぜた場 合と, コンクリートからウェットスクリーニングして得 たモルタルとの強度を比較すると, 標準養生した供試体 の場合は, 明確にウェットスクリーニングしたモルタル の方が 10〜20\% 程度強度が大きくなっており, 急速硬 化モルタルの場合でも全体の傾向としては標準養生の場 合と同様であるが，一部異なったものも見られる.ウェ ットスクリーニングの有無による急速硬化モルタルの強

度の差が，今回の実験では前に報告した場合 ${ }^{1)}$ と比べて 必ずしも顕著ではないのは，実験場所が異なったため練 りまぜ前の粗骨材表面の湿潤状態, および粗骨材中に含

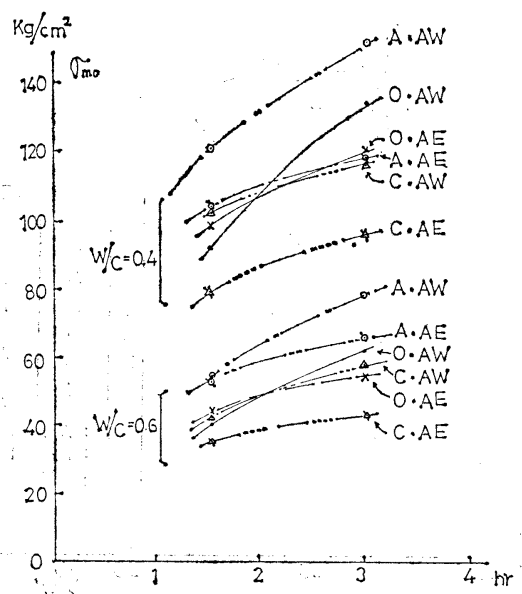

図一9 急結剤 PR2 を用いた急速硬化モルタル の強度特性 
まれる微粒分の量の相違などが影響したからと思われ る.

次に, 得られた結果を用いて本方法の強度推定の精度 を検討してみる. まず, コンクリート強度と水セメント 比との関係は, セメントの銘柄, 粗骨材の管理状態, 混 和剤の有無, 空気量の大小などによって異なるが,ここ ではすべてを同一の図に表わした．ただし，空気量の大 小は次のような方法で考慮した. すなわち, 空気を同体 積の水に換算して $\mathrm{AE}$ コンクリートの水セメント比を プレーンコンクリートの水セメント比に換算することと したのである. この場合, 粗骨材の最大寸法が $25 \mathrm{~mm}$ であるので, プレーンコンクリートの混入空気量は普通 $1.5 \%$ 程度であるが, 混和剤の効果を考虑し, $\mathrm{AE}$ コン クリートで $2.5 \%$ を越える分の空気量を水に換算して 修正することにしたのである.このようにして定められ た水セメント比を, ここでは換算水セメント比とよぶこ とにする。

図一10 亿表一5 の值および前論文 ${ }^{1)}$ の実験も合わせ て強度と換算セメント水比との関係を示した. この結 果, セメントの銘柄, 混和剤の種類などの要因はコンク リートの強度に大きくは現われておらず，ここではこれ らを区別しないで取り扱うことができるものと思われ た.したがって, ここでは換算セメント水比を用いて単 一の $\sigma_{28}-C / W$ 直線を最小二乗法によって求めることに した.このようにして求めた式 (1)の $k_{1}, k_{2}$ は次のよ うな值となる.

$$
k_{1}=237, k_{2}=-65
$$

次に同様にしてモルタルのみを練りまぜた場合の急速

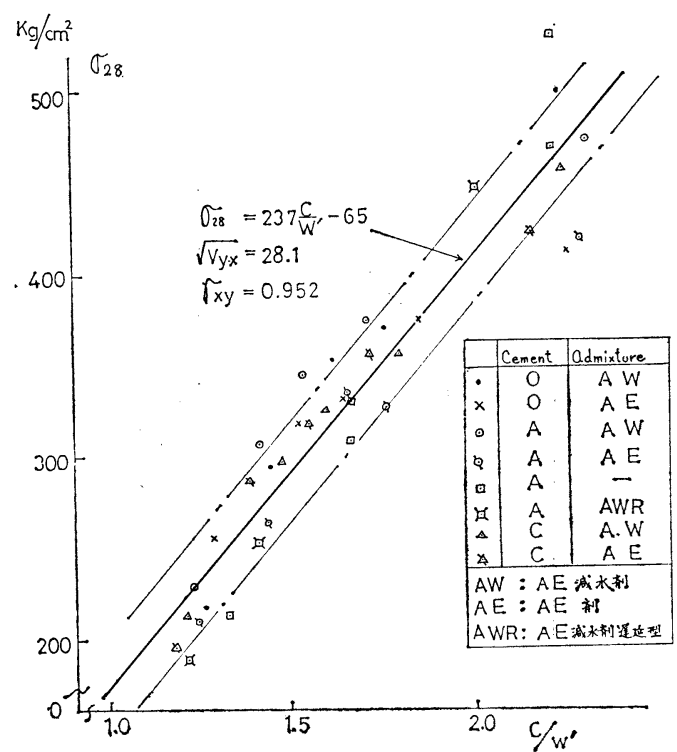

図一10 コンクリートの圧縮強度 $\sigma_{28}$ と換算セメ ント水比 $\boldsymbol{C} / \boldsymbol{W}^{\prime}$ との関係の実験結果

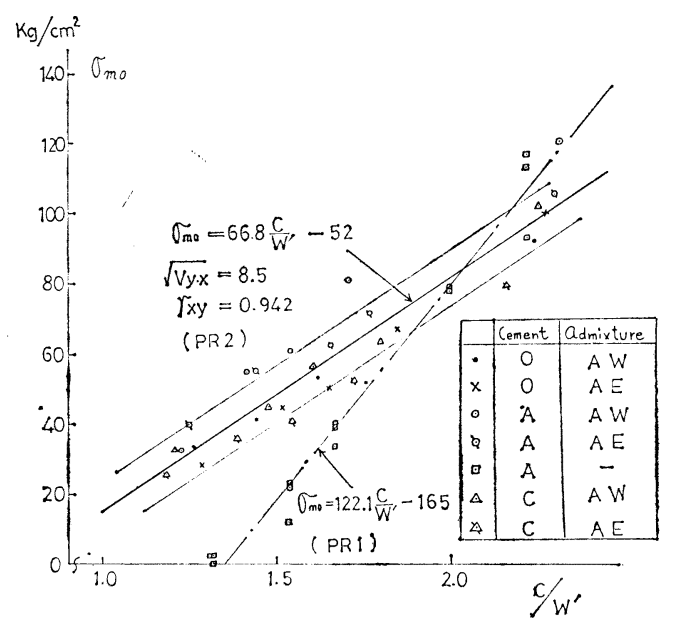

図-11 モルタルの急速硬化強度 $\sigma_{m 0}$ と換算セメ ント水比 $\boldsymbol{C} / \boldsymbol{W}^{\prime}$ との関係の実験結果 (高温養生 1.5 時間の場合)

硬化モルタルの強度とセメント水比との関係について も，表一5 から換算セメント水比を用いて求めると次の ようになる。

$m_{01}=66.8, m_{02}=-51.8$

（高温養生 1.5 時間の場合）

$m_{01}=79.2, m_{02}=-55.4$

（高温養生 3.0 時間の場合）

なお，改良以前の急結剤 (PR1) を用いた場合の $m_{01}$, $m_{02}$ はそれぞれ次の值である。

$m_{01}=122.1, m_{02}=-165.1$

（高温養生 1.5 時間の場合） $m_{01}=111.2, m_{02}=-116.0$

（高温養生 3.0 時間の場合）

図一11 に示すように，急速硬化モルタル強度は,セメ ントの銘柄，混和剤の種類によりわずかな差も見られる が，同じ直線で表わしても誤差はそれほど大きくならな いと考えられる. セメントの銘柄および混和阂の種類に 無関係に急速硬化判定方法の一般的な推定式が定まるこ とは，この方法の有用性を一段と高めるものと思われ る.これは急結剤として強アルカリ剤を加えて改良した ものを用いたことに起因していると思われる.

図一11 に,合わせて改良前の急結剂によるデータも示 したが，材令 1.5 時間の場合が特に改良急結剤を用い たものと異なっており, セメントの風化の影響の除去, 高温養生時間の短縮化, コンクリート強度推定値の精度 向上などに改良急結剤がきわめて有効であることが示唆 されたものと思われる。

次に, ウェットスクリーニングの効果について考虑す ることにする. 前論文 ${ }^{11}$ に示した実験結果と同様, 今回 の実験結果についてもウェットスクリーニング効果と表 


\begin{tabular}{|c|c|c|c|c|c|}
\hline \multirow{2}{*}{ No. } & \multirow{2}{*}{$\begin{array}{c}\text { 実椡值 } \\
\sigma_{28}\end{array}$} & \multicolumn{2}{|c|}{ 推定式 (1) } & \multicolumn{2}{|c|}{ 推定式 (2) } \\
\hline & & 推定值 & 推/実 & 推定值 & 推/実 \\
\hline 1 & 216 & 250 & 1.16 & 227 & 1.05 \\
\hline 2 & 351 & 305 & 0.87 & 297 & 0.85 \\
\hline 3 & 498 & 442 & 0.89 & 470 & 0.94 \\
\hline 4 & 254 & 281 & 1.11 & 266 & 1.05 \\
\hline 5 & 331 & 331 & 1.0 & 220 & 1.00 \\
\hline 6 & 412 & 433 & 1.05 & 459 & 1.11 \\
\hline 7 & 293 & 283 & 0.97 & 269 & 0.92 \\
\hline 8 & 369 & 312 & 0.85 & 306 & 0.83 \\
\hline 9 & 317 & 299 & 0.94 & 289 & 0.91 \\
\hline 10 & 374 & 348 & 0.93 & 350 & 0.94 \\
\hline 11 & 228 & 256 & 1.12 & 234 & 1.03 \\
\hline 12 & 343 & 348 & 1.01 & 351 & 1.02 \\
\hline 13 & 472 & 499 & 1.06 & 542 & $1.1 \mathrm{~g}$ \\
\hline 14 & 209 & 268 & 1.28 & 249 & 1.19 \\
\hline 15 & 333 & 364 & 1.09 & 372 & 1.12 \\
\hline 16 & 418 & 469 & 1.12 & 504 & 1.21 \\
\hline 17 & 305 & 308 & 1.01 & 301 & 0.99 \\
\hline 18 & 374 & 356 & 0.95 & 361 & 0.97 \\
\hline 19 & 263 & 299 & 1.14 & 289 & 1.10 \\
\hline 20 & 327 & 337 & 1.03 & 337 & 1.03 \\
\hline 21 & 212 & 233 & 1.1 & 205 & 0.97 \\
\hline 22 & 325 & 299 & 0.92 & 289 & 0.89 \\
\hline 23 & 457 & 463 & 1.01 & 496 & 1.09 \\
\hline 24 & 195 & 232 & 1.19 & 205 & 1.05 \\
\hline 25 & 317 & 277 & 0.87 & 261 & 0.82 \\
\hline 26 & 422 & 421 & 1.0 & 443 & 1.05 \\
\hline 27 & 297 & 292 & 0.98 & 281 & 0.95 \\
\hline 28 & 356 & 321 & 0.9 & 317 & 0.89 \\
\hline 29 & 286 & 282 & 0.99 & 268 & 0.94 \\
\hline 30 & 355 & 302 & 0.85 & 292 & 0.82 \\
\hline \multicolumn{2}{|c|}{ 平 均 值 } & \multicolumn{2}{|c|}{$\bar{x}=1.013$} & \multicolumn{2}{|c|}{$\bar{x}=0.997$} \\
\hline \multicolumn{2}{|c|}{ 標準偏差 } & \multicolumn{2}{|c|}{$\sigma_{n}=0.107$} & \multicolumn{2}{|c|}{$\sigma_{n}=0.104$} \\
\hline \multicolumn{2}{|c|}{ 変 動 係数 } & \multicolumn{2}{|c|}{$\frac{\sigma_{n}}{\bar{x}}=0.105$} & \multicolumn{2}{|c|}{$\frac{\sigma_{n}}{\bar{x}}=0.104$} \\
\hline \multicolumn{6}{|c|}{$\begin{array}{l}\text { 推定式 }(1) \text { : 最小二乗法による } \\
\quad \sigma_{28}=2.98 \sigma_{m 1.5 h}+144\left(\mathrm{~kg} / \mathrm{cm}^{2}\right)\end{array}$} \\
\hline & & $=3.77 \sigma_{r}$ & & & \\
\hline
\end{tabular}

現すると, 式 (3) の定数は次のようになる.

$a_{1}=0.94, a_{2}=6.9$ (高温養生 1.5 時間の場合)

$a_{1}=0.88, a_{2}=11.4$ (高温養生 3.0 時間の場合)

以上の結果を推定式である式（4）に代入して求めると, 改良急結剤 (PR2) を用い, 高温養生 1.5 時間および 3.0 時間による推定式はそれぞれ式 (9),(10) となる.

$\sigma_{28}=3.77 \sigma_{m 1.5 h}+93 \mathrm{~kg} / \mathrm{cm}^{2}$

(高温養生 1.5 時間の場合)

$\sigma_{28}=3.4 \sigma_{m 3.0 h}+62 \mathrm{~kg} / \mathrm{cm}^{2}$

(高温養生 3.0 時間の場合)

それぞれの推定值および実測值は表一6 亿示す通りであ る. また,このうちの高温養生 1.5 時間の場合を示し たのが図一12である.な㨦定式として $\sigma_{m}$ と $\sigma_{28}$ と の実測值から直接最小二乗法によって求めた式も図およ び表に示してある.
表一6（2） コンクリートの $\sigma_{28}$ の実測値

と 3.0 時間推定値 $\left(\mathrm{kg} / \mathrm{cm}^{2}\right)$

\begin{tabular}{|c|c|c|c|c|c|}
\hline \multirow{2}{*}{ No. } & \multirow{2}{*}{$\begin{array}{c}\text { 実測值 } \\
\sigma_{28}\end{array}$} & \multicolumn{2}{|c|}{ 推定式 (1) } & \multicolumn{2}{|c|}{ 推定式 (2) } \\
\hline & & 推定値 & 推/実 & 推定値 & 推/実 \\
\hline 1 & 216 & 258 & 1.19 & 238 & 1.10 \\
\hline 2 & 351 & 313 & 0.89 & 309 & 0.88 \\
\hline 3 & 498 & 457 & 0.92 & 490 & 0.98 \\
\hline 4 & 254 & 272 & 1.07 & 256 & 1.01 \\
\hline 5 & 331 & 333 & 1.01 & 334 & 1.01 \\
\hline 6 & 412 & 449 & 1.09 & 480 & 1.17 \\
\hline 7 & 293 & 287 & 0.98 & 275 & 0.94 \\
\hline 8 & 369 & 349 & 0.95 & 354 & 0.96 \\
\hline 9 & 317 & 310 & 0.98 & 304 & 0.96 \\
\hline 10 & 374 & 338 & 0.90 & 340 & 0.91 \\
\hline 11 & 228 & 255 & 1.12 & 235 & 1.03 \\
\hline 12 & 343 & 351 & 1.02 & 356 & 1.04 \\
\hline 13 & 472 & 516 & 1.09 & 565 & 1.20 \\
\hline 14 & 209 & 261 & 1.25 & 243 & 1.16 \\
\hline 15 & 333 & 362 & 1.09 & 370 & 1.11 \\
\hline 16 & 418 & 465 & 1.11 & 501 & 1.20 \\
\hline 17 & 305 & 321 & 1.05 & 318 & 1.04 \\
\hline 18 & 374 & 366 & 0.98 & 375 & 1.00 \\
\hline 19 & 263 & 293 & 1.11 & 282 & 1.07 \\
\hline 20 & 327 & 336 & 1.03 & 338 & 1.03 \\
\hline 21 & 212 & 222 & 1.05 & 193 & 0.91 \\
\hline 22 & 325 & 295 & 0.91 & 286 & 0.88 \\
\hline 23 & 457 & 449 & 0.98 & 480 & 1.05 \\
\hline 24 & 195 & 223 & 1.14 & 194 & 0.99 \\
\hline 25 & 317 & 262 & 0.83 & 243 & 0.77 \\
\hline 26 & 422 & 400 & 0.95 & 419 & 0.99 \\
\hline 27 & 297 & 291 & 0.98 & 280 & 0.94 \\
\hline 28 & 356 & 310 & 0.87 & 304 & 0.85 \\
\hline 29 & 286 & 275 & 0.96 & 260 & 0.91 \\
\hline 30 & 355 & 291 & 0.82 & 280 & 0.79 \\
\hline 平 & 均 & \multicolumn{2}{|c|}{$\bar{x}=1.011$} & \multicolumn{2}{|c|}{$\bar{x}=0.996$} \\
\hline \multicolumn{2}{|c|}{ 標準偏 差 } & \multicolumn{2}{|c|}{$\sigma_{n}=0.102$} & \multicolumn{2}{|c|}{$\sigma_{n}=0.108$} \\
\hline \multicolumn{2}{|c|}{ 変動係数 } & \multicolumn{2}{|c|}{$\frac{\sigma_{n}}{\bar{x}}=0.101$} & \multicolumn{2}{|c|}{$\frac{\sigma_{n}}{\bar{x}}=0.109$} \\
\hline \multicolumn{6}{|c|}{$\begin{array}{c}\text { 推定式 (1) : 最小二乗法による } \\
\sigma_{28}=2.68 \sigma_{m 3.0 h}+119\left(\mathrm{~kg} / \mathrm{cm}^{2}\right) \\
\text { 推定式 } \\
\text { (2) : 計算式による }\end{array}$} \\
\hline \multicolumn{6}{|c|}{$\sigma_{28}=3.40 \sigma_{m 3.0 h}+62\left(\mathrm{~kg} / \mathrm{cm}^{2}\right)$} \\
\hline
\end{tabular}

このように, 推定值と実測值はきわめてよく一致して おり, 実測值に対する推定值の比率の変動係数は, 高温 養生 1.5 時間および 3.0 時間の場合ともに約 $10 \%$ であ り, コンクリートの $\sigma_{28}$ 自身の変動が管理のよい場合で も通常 $5 \%$ 以上はあることを考えれば，材令 1.5 時間 あるいは 3 時間でこの程度の精度が得られることは画期 的なことと考えられる. また, 実測值から直接最小二乗 法によって求めた式と, 式 (4) の関係を用いて計算に よって求めた推定式とで, 式の係数は若干異なっている が, 求まる推定值の精度はほぼ同様であり,このことは 精度のよい推定式が強度判定作業の開始と同時に求めら れることを意味するものである. なお, 単一の銘柄のセ メントと単一の混和剤を用いたコンクリートについて固 有の推定式を上述の方法で求め, これを用いて $\sigma_{28}$ を推 定すればさらに精度のよくなることは当然である.この 


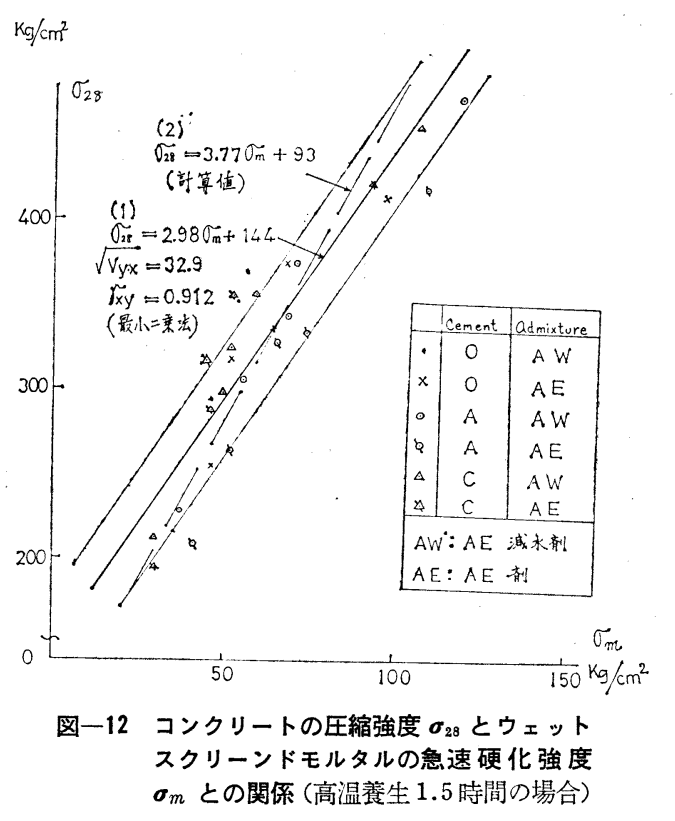

実験の場合，各材料ごとの推定式を用いて推定值と実測 值を比較した場合, 推定值と実測值との比率の変動係数 は約 7\% であった。

以上のように，改良した急結剤を用い，セメントの銘 柄，混和剤の種類を変えたコンクリートによる実験の結 果, 本方法はきわめて短時間のうちに十分な精度でコン クリートの強度を判定できることが明らかになったので ある・

ただし，別の実験でコンクリートの練りまぜを手練り で 1 分間程度としたきわめて不十分な練りまぜのコンク リートを試験したところ, ウェットスクリーンドモルタ ルの強度は十分所定の強度となっても，コンクリートの 標準供試体はブリージングなどの影響が大きくなって, モルタルと粗骨材との付着が害され，実測強度が $70 \%$ 程 度に低下した. 特に水セメント比の大きい場合にこの傾 向が著しい，したがって本方法によるコンクリート強度 判定は, 普通に練りまぜられた分離の少ないコンクリー 卜に用いるものとし，この条件が満足されない場合に は, 推定した強度をある程度割り引いて考える必要があ ろら.

\section{7. 強度判定の手順}

本方法によるフレッシュコンクリートの強度判定の手 順は, 図一13 に示す通りである.採取するコンクリート 試料の量は用いる型枠の寸法, 供試体の数によって異な るが，断面積 $10 \mathrm{~cm}^{2}$, 長さ $5 \mathrm{~cm}$ の専用の 3 連型枠を 1 個用いる場合には, 約 $5 \mathrm{~kg}$ (または約 $2.2 l$ ) のフレ ッシュコンクリートを採取し，これを $5 \mathrm{~mm}$ ふるいで
ウェットスクリーニング

しでこれから $500 \mathrm{~g} の$ モルタル試料を計りと る.これに $5 \mathrm{~g}$ 程度の 一定量の急結剂 (PR2) を添加して 1 分間練りま ぜ,ただちに専用型枠に 詰める、これをあらかじ め $70^{\circ} \mathrm{C}, 100 \% \mathrm{RH}$ に保 っておいた恒温恒湿装置 に入れ，1 時間以上の一 定時間養生して急速硬化

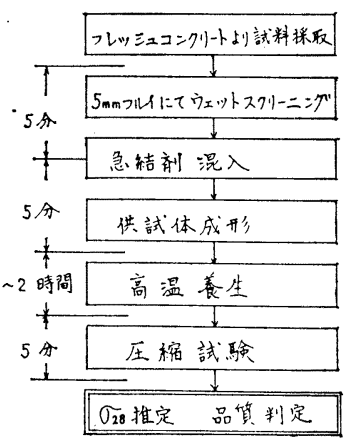

図一13 兔速硬化判定方法の 流れ図 モルタル供試体を得る.これを圧縮試験し, その結果か らあらかじめ求めておいた推定式を用いて，ただちにコ ンクリートの材令 28 日の強度を推定する.

型枠に JIS R 5201 のセメント強さ試験用型枠を用い る場合には，コンクリート試料として約 $15 \mathrm{~kg}$ を採取 し, ウェットスクリーニングしたモルタルを $2.5 \mathrm{~kg}$ 計 りとって試験をすればよい。

改良急結剂と専用型枠とを用いれば，高温養生 1 時間 でもある程度の精度でコンクリート強度を推定すること が可能であるが, はじめは高温養生 1.5 時間程度とし, 実績の積み重ねによって徐々に養生時間を短縮していく のも一つの方法である.

工事に使用するセメントおよび試験に用いる急結肪な どを用いて強度推定式を定めるには，次のようにするの がよい，使用するセメントおよび細骨材を用いて 表一7 の配合のモルタルを練り，これを急速硬化させて， $\sigma_{m 0^{-}}$ $C / W$ 直線を最小二乗法によって定める. 式 (1) の $k_{1}$, $k_{2}$, 式 (3) の $a_{1}, a_{2}$ として仮りに 6. で用いた係数を 用いれば，材料特性を考慮した強度推定式が品質検查の 開始と同時に求められる.このようにして求めた強度推 定式を用いて品質検查業務を開始し, やがて材令 28 日 の実測コンクリート強度のデータが出た段階で, 急速硬 化モルタル強度と材令 28 日の実測コンクリート強度と を直接対比して, 強度推定直線を修正していくのがよ い. なお, 普通ポルトランドセメントを用いた普通骨材 コンクリートの概略の強度推定式としては, 改良急結肪

\section{表一7 強度推定直線作成用モルタル} の配合例

\begin{tabular}{l|c|c|c|c|c}
\hline$C / W$ & $\begin{array}{c}W \\
(\mathbf{g})\end{array}$ & $\begin{array}{c}C \\
(\mathbf{g})\end{array}$ & $\begin{array}{c}S \\
(\mathbf{g})\end{array}$ & $S / C$ & $\begin{array}{c}\text { Total Weight } \\
(\mathbf{g})\end{array}$ \\
\hline 2.2 & 65 & 143 & 292 & 2.04 & 500 \\
2.0 & 65 & 130 & 305 & 2.35 & 500 \\
1.8 & 65 & 117 & 318 & 2.72 & 500 \\
1.6 & 70 & 112 & 318 & 2.84 & 500 \\
1.45 & 70 & 102 & 328 & 3.22 & 500 \\
1.3 & 70 & 91 & 339 & 3.73 & 500 \\
\hline
\end{tabular}


（PR 2）を用いる場合，種々の実験結果から得た式（9） が参考になると思われる．AE 剂などの混和剤が用いら れているコンクリートの場合でも, 空気量の影響を水量 に換算して評価すれば, プレーンコンクリートとほぼ同 じに扱えるので, $\sigma_{m 0}-C / W$ 直線を求める際には, 特殊 な場合を除き，混和剤を用いないで值を求めてもよいも のと思われる.

\section{8. コンクリート強度検査システム}

JIS A 5308 「レデーミクストコンクリート」ではコ ンクリートの強度検查を $150 \mathrm{~m}^{3}$ に 1 回行うことを規定 しているが, レデーミクストコンクリートはいわば半製 品であるため, できれば各運搬車ごとになんらかの試験 を行うのがよいと思われる. しかし本方法がいかに簡便 な方法であるとはいえ, 全運搬車のコンクリートを検查 することは一般の場合きわめて煩雑であり, 無理が生ず る場合がある.そこで，スランプ試験方法よりさらに簡 易なチェック方法を開発して, 全運般車のコンクリート を検查するとともに，本方法によって運搬車の最初の 1 台目と, 以後簡易チェックで疑問のあるコンクリートな どを抜き取り式に検查するのがよいと思われる．検査の 工程から考えて午前 2 回, 午後 2 回程度でスタートする のがよいであろう.本方法が軌道に乗れば, 材令 28 日 の標準供試体による試験は品質確認の意味で行うことと し， 1 打込み区画につき 1 回, あるいは 2 回程度行えば よいであろう。

次に問題となるのは, 誰れが試験の作業を担当するか である. 元来, 検査は購入者の責任で行うものであり, 米国などのように発注者が独立の検查機関に依頼して行 わせるのが理想と思われる ${ }^{7), 8)}$. 本方法のような即時判 定方法が今後普及する場合, 今までのわが国における慣 習にとらわれず，合理的な新しい検查システムを検討す ることが必要である.

わが国の公共土木工事を対象として考えてみると、コ ンクリート工事の検查に関係のある機関として次が考え られる。

(1) 発注者

（2） 発注者が依頼した民間の施工管理会社

(3) 施工業者

（4）レデーミクストコンクリート会社

レデーミクストコンクリートを直接購入するのは一般に 施工業者であるが, 公共土木工事の場合, 普通注注者 の意向を無視して施工業者がコンクリートを購入するこ とはできない，そこで，本方法のようなコンクリート強 度即時判定方法が健全に普及するためには, スタートと して上記の（1）または（2）の機関が責任をもって実施
し, 実績を積み重ねた 後に, 場合によっては（3）の機 関で行わせることを検討したらよいであろう．(4) の機 関に行わせることは検查の独立性から考えて好ましくな く，また検査に対する軽視にもつながるであろう。 なお本方法を工事現場で実施することにより，レデー ミクストコンクリート工場での品質管理がいっそう注意 深く行われるようになるであろうし，またコンクリート を打ち込む側の技術者もコンクリートの品質に対する関 心が深まるとともに, 施工中のコンクリートの品質に関 して自信を持って仕事を進めることができ, コンクリー ト工事全般について, 生きた品質管理を期待することが できると思われる.

本方法のような即時判定方法を基本とし, コンクリー トの硬化後に行うシュミットハンマーなどによる検査を も含めて総合的なコンクリートの品質検查システムを確 立すれば,コンクリート構造物に鋼に勝るとも劣らない 品質の信頼性を持たせることも可能であると思われる.

\section{9. 結言}

急速硬化によるコンクリート強度即時判定方法の実用 化を進めるにあたり問題となる事柄について, 以上に述 べたような検討を行った. 研究の方法として, 問題点の 摘出とその解決方法に重点を置いたため, 研究が必ずし も系統的に行われなかったが, 本研究の範囲で急速硬化 によるコンクリート強度即時判定方法は十分に実用的な 域に達したものと考えられる。

本研究において得られたおもな成果をここに列挙すれ ば, 次の通りである.

（1）セメントの風化が急速硬化モルタルの強度に過 度に大きく影響することが判明し，これがこの方法によ る推定の精度を低下させる原因の 1 つになり得ることが 明らかとなった。

そこで，これに対処する方法として急結剤の改良を行 い, 本方法のための専用の急結剤を開発して, この点を 解決した. すなわち, 強アルカリ剂を急結剤に一定量添 加することにより，セメントの風化の影響を除くことが できたのである.

（2）改良した急結剤を用いることにより，セメント の銘柄, ロット, および保管状態などの相違の影響, 混 和剤の影響などによる急速硬化モルタル強度の相違を相 当に少なくすることができ, 種々の普通ポルトランドセ メントを用いたコンクリートに共通の標準的な強度推定 式を提案することができた.

（3）改良急結剂の使用により, 急速硬化モルタルの 強度発現が相当に早くなり, 養生時間の短縮および推定 值の精度向上を計れることが示された. すなわち, 一連 
の実験の結果, 材令 1.5 時間 でセメントの銘柄に関係 なく,コンクリートの材令 28 日の強度を変動係数約 10\% で推定することができたのである. なお，同一の 銘柄の材料の場合はこの変動係数が約 $7 \%$ であった.

（4）高炉セメントを用いた急速硬化モルタルにより 実験を行った結果, 普通ポルトランドセメントの場合と 同様に高炉セメントを用いたコンクリートに対しても本 方法を適用できることが示された.

（5） $\mathrm{AE}$ コンクリートの空気量の一部を同体積の水 に換算した換算水セメント比の概念により, プレーンコ ンクリートと同一の強度一セメント水比直線を $\mathrm{AE}$ コン クリートにも適用することができた．これにより，即時 判定を行う際に必要となる強度推定式を容易に作成でき ることが明らかになった。

（6）現場試験用恒温恒湿装置および圧縮試験機を試 作し, 現場実験に適用した結果, これらの機器は工事現 場におけるコンクリートの強度検査にきわめて有用であ り，かつ合理的なものであることが明らかとなった。

（1）実際の工事現場において, 現場に納入されたレ デーミクストコンクリートの品質検査実験を行った結 果, 本方法が現場におけるコンクリート強度即時判定方 法として十分実用的であり, 現場コンクリートの品質検 查および管理の内容を飛躍的に向上させ得ることが確か められた.

（8）本方法のための専用型枠，すなわち断面が 10 $\mathrm{cm}^{2}$ となるように一辺を $\sqrt{10} \mathrm{~cm}$ とする型枠を試作し， 養生時間の短縮, 試験の合理化を計ることが可能となっ た.

「急速硬化によるコンクリート強度即時判定方法」は， 提案されてからいまだ日も浅いため，実用にあたって新 しい問題点, 改良すべき点, あるいは改良可能な点など が今後出てくるものと思われる.

本方法のような迅速判定方法の採用にあたり，従来か ら行われている材令 28 日の強度試験との組み合わせの 問題，スランプ試験よりさらに簡単なフレッシュコンク リートの簡易チェック方法の開発, 硬化後のコンクリー
トの簡易検査方法の採用などを検討し，これらを組み合 わせた総合的なコンクリートの品質検査・管理システム を確立することが今後の重要な課題であろう.

謝辞：本研究を行うにあたり，首都高速道路公団 の加藤正晴氏, 阿部竜介氏, 森山市三氏, 大内雅博氏, 飯野忠雄氏, 秋元泰輔氏ほか多くの職員の方々から種々 のご配慮を賜わりました．厚く御礼を申し上げます．ま た実験に際しご協力いただいた信田佳延君，秋山正君を はじめとする研究室の大学院学生および卒業生諸君, 日 曹マスタービルダーズ (株) の秀島節治氏，児玉和己 氏, 中川 脩氏, 林 俊彦氏, 現場実験にご協力いただ いた (株) 新井組の東森 実氏, ならびに試験機器の試 作にご協力いただいた(株)丸東製作所の佐藤 博氏に深 甚の謝意を表します.

なお本研究は国分正胤先生をはじめとする諸先生の暖 かいご指導，ご支援を受けて行ったものであり，ここに 心から感謝する次第であります.

\section{参考文献}

1）池田尚治：急速硬化によるコンクリート強度即時判定方 法に関する研究, 土木学会論文報告集, 第 255 号, 1976 年 11 月.

2）池田尚治：打込み時点にコンクリート強度を判定する方 法に関する研究, 土木学会第 31 回年次学術講演会講演概 要集第 5 部, $V-37$, 昭和 51 年 10 月.

3）池田尚治・信田佳延・秋元泰輔：急速硬化によるコンク リート 強度即時判定法の現場実験, 土木学会関東支部第 4 回年次研究発表会講演概要集, 昭和 52 年 1 月.

4）神田 衛・鈴木 脩・石渡章介：夏期におけるコンクリー トの強度の低下現象に関する一考察, コンクリートジャ ーナル, Vol. 8, No. 11, Nov. 1970.

5）児玉武三・宮脇秀年：セメントの風化がその物理的性質 におよぼす影響，セメント技術年報 (第 10 回),pp. 78〜 83 , 昭和 31 年.

6）真鍋敏雄：セメントの風化におよぼすセッコウの影響， セメント技術年報 (第10回), pp. 74〜 77, 昭和 31 年.

7) ACI Symposium by Committee 311 : Inspection of Concrete, ACI Journal, pp. 269 290, June 1975.

8) ACI New Jersey Chapter Report : Responsibility in Concrete Inspection, ACI Journal, pp. 201 218, April 1974.

(1977.5.16 - 受付) 